\title{
Requirements of Applying Digital Economy in Sports
} Organizations

\section{"Dr/ Hassan Ahmed Attia Elshafaei **Dr/ Nadia Lofty Abdel Fattah Moawad Research Introduction and Problem:}

As digital revolution involvement in daily life increases, new terminology emerged including digital economy or knowledge economy and apart from traditional economy branches, this new type of economy has characteristics expecting redevelopment with its different dimensions.

Accordingly digital economy represented a new perspective in business environment, ideology and philosophy, attitude and practice, traditional business forms are not able to deal with this ever renewable dynamic age. (42).

\section{Accordingly Egypt} recognized the importance of joining globalization age; increasing its competitive ability and reaching international consumer anywhere, through applying ecommerce as a basis of national economy it hold an international committee of specialists in information and decision support center related to prime ministry. $(7: 42)$

Digital economy is identified as economy depending an information technology and information technology means every stage of making information beginning from culture, training and teaching passing through making computer hardware and ending by computer software. (43)

shall Also digital economy reaction, integration and coordination between information technology and communication technology from one side and national economy and international sectorial economy from the other side. (38:223)

Knowledge economy is a digital economy in terms of

professor of sports management Faculty of Physical Education for Girls in Alexandria University Department.

" Teacher Administration Faculty of Physical Education for Girls in Alexandria University Department.

Assiut Journal For Sport Science Arts 
relationship to digital technology enabled to expanding, transferring, storing and treating information, quick distribution, marketing and consumption, regardless of who produced or interact with, with no lingual restrictions and local cultures, scientific knowledge was converted to digital form. (4:12) (1:207)

Accordingly activating science and technology organization through adopting a policy for and a strategy for executing this policy and through strengthening links and bridges between this organization stages, may result in having a national system for creation increasing competition ability and achieving permanent development needed for the Arab world for the twenty first century. (31:34)

From the above, the researchers conclude that digital economy depends on two bases, e-commerce, information technology or information industry, as information industry created real e-commerce as depending on computers, communication and all new technology means. Of characteristics and basics of digital economy is easy access to information as success and growth of digital economy may depend on ability of individual and organizations to participate in information networks and websites, also information technology plays a main role in increasing economic growth rates, capital investment and internal and external ecommerce. (7:232) (34:120)

There are some challenges and restrictions facing applying digital economy in some organizations such as absence of main infrastructure of this type of new commerce, non clear future vision for emarketing for managers of some companies and non sufficient internet in some developing countries. (45)

International bank report for (2005) indicates that international technology exports of Arab countries reached $(2 \%)$ while developed countries reached (36\%), East Asia countries reached (29\%) and Latin America reached (2\%) but in case average internet users number in developed countries for (2003) reached (480) for every one thousand people and average internet users number in Arab countries reached (49) for 
every thousand people for the same year to clarify digital gap. (16:34) (26:16)

As focusing on Arab sites events on internet for different organizations and commercial authorities in the Arab world increased sites established in the previous years began to add e-marketing service and other e-commerce services as this study proves that e-commerce activities in Arab environment is increasing. (14)

\section{Table No. (1)}

Statistics of internet users worldwide from (2000-2016)

\begin{tabular}{l|c|c|c|c|c|c}
\hline \hline $\begin{array}{c}\text { World } \\
\text { Zones }\end{array}$ & $\begin{array}{c}\text { Number of } \\
\text { Population }\end{array}$ & $\begin{array}{c}\text { World } \\
\text { Population } \\
\text { Percentage }\end{array}$ & $\begin{array}{c}\text { Number of } \\
\text { Internet } \\
\text { Users till 30 } \\
\text { June 2016 }\end{array}$ & $\begin{array}{c}\text { Internet } \\
\text { Users } \\
\text { Percentage }\end{array}$ & $\begin{array}{c}\text { Internet } \\
\text { Spread } \\
\text { Percentage } \\
\text { From 2000 } \\
\text { to 2016 }\end{array}$ & $\begin{array}{c}\text { Internet } \\
\text { Users } \\
\text { Percentage } \\
\text { Worldwide }\end{array}$ \\
\hline \hline Africa & 1.185 .529 .578 & $16.2 \%$ & 339.283 .342 & $28.6 \%$ & $6.415 \%$ & $9.4 \%$ \\
\hline Asia & 4.052 .652 .889 & $55.2 \%$ & 1.792 .163 .654 & $44.2 \%$ & $9.467 \%$ & $49.6 \%$ \\
\hline Europe & 832.073 .224 & $11.3 \%$ & 614.979 .903 & $73.9 \%$ & $2.485 \%$ & $17.0 \%$ \\
\hline Middle East & 246.700 .900 & $3.4 \%$ & 132.589 .765 & $53.7 \%$ & $5.936 \%$ & $3.7 \%$ \\
\hline $\begin{array}{l}\text { Latin } \\
\text { America }\end{array}$ & 626.054 .392 & $8.5 \%$ & 384.751 .302 & $61.5 \%$ & $4.029 \%$ & $10.6 \%$ \\
\hline $\begin{array}{l}\text { North } \\
\text { America }\end{array}$ & 359.492 .293 & $4.9 \%$ & 320.067 .193 & $89.0 \%$ & $1.196 \%$ & $8.9 \%$ \\
\hline Australia & 37.590 .704 & $0.5 \%$ & 27.540 .654 & $73.3 \%$ & $4.261 \%$ & $0.8 \%$ \\
\hline $\begin{array}{l}\text { Total } \\
\text { International }\end{array}$ & 7.340 .093 .980 & $100 \%$ & 3.611 .375 .813 & $49.2 \%$ & $4.900 \%$ & $100 \%$ \\
\hline
\end{tabular}

From table No. (1) It is clear that internet users' number is increasing worldwide as well as traditional marketing transformation to internet marketing "e-marketing", according Egypt established the first E-Arab commerce in Cairo, Egypt telecom aiming at offering Arab service through internet through E-Arab market to activate Arab international trade. (38:36)

As the world focused an e-commerce that became a tangible fact under the current environment and due to the effect of this commerce on markets, organizations performance and competitive capacities as e-commerce will be common in many organizations and individuals through this century worldwide. (46)

E-commerce became a very important tool as international e-commerce, according to the last statistics reached (1300) billion dollars while the E-

Assiut Journal For Sport Science Arts 
Arab commerce reached (3) billion dollars. (41)

Medhat Ramadan (2001) defines it as commercial process performance between commercial partners by using a developed information technology also it is some digital deals related to commercial activities between project themselves, projects and individuals and projects and management. (25:12)

\section{Khairy}

Moustafa

Kenana (2009) states that ecommerce means executing selling and purchasing goods and service and information through internet in addition to other international commercial networks. (22:51)

Also e-commerce will play a future vital role in marketing and trade exchange increase despite their nowadays' results are not high in some states, however there is an attitude to develop his beginning and accordingly e-commerce will be a transitional phase in international economy change. (44)

Accordingly e-market for trade points system was built to increase commercial activity and Arab countries in between trade and opening emarkets to exchange goods and services through e-networks as the site included commercial opportunities exchange services, commercial manuals and e-catalogues. (23:62)

E-commerce was characterized by many characteristics distinguishing its form traditional commerce like non existence of a geographic place where sellers and purchasers can meet, rather meeting takes place via internet and both parties are rarely knowing each other, rather exchanging is made between parties without seeing each other. (40)

Also

Ibrahim

Mohamed Darwish (2002) added that e-commerce has many advantages from which companies can profit including a more effective marketing and higher profits as an effective means of reaching all the world markets with no interruption all day and yearlong and at the least expenses. (19:6)

E-commerce is a development and change tool and will increase in future to be a strategic importance and a revolution in the method from which commercial activities are achieved in addition to the internet clear effect on commercial business and the 
great increase in number of individuals using internet worldwide every year. (36:124) Accordingly, the researchers believe that e-commerce represented a digital economy aspect constituting a main factor in general state economy and in the field of sports specifically, accordingly ecommerce is an investment branch, through which sports organizations economy can be developed.

Through results and recommendations of the previous studies such as study of Khalid Abdel attia (2000) (21) or the most important results is that under the new economic system, technology economic sovereignty emerged through participation in supporting all sports activity and festivals, study of Sanaa Abo zid (2005)(35) resulted in weak investment for governmental sites working in e-commerce such as exporting through internet, most of Arab countries discourage ecommerce, study of Hussein Omar El Semry and Ashraf Sobhy Mohamed Hussein (2006)(17) that recommended the importance of developing and modernizing communication networks and information bases in sports and youth authorities to use technology in managing all elements of sports industry and linking to ministry of investment as an investment field, study of Mahmoud Kirziz and Mariam Yehyawy (2007)(24) recommends the importance of supporting and encouraging e-commerce specially for advanced technology companies such as programs and systems companies, study of Hatem Ossman Ali (2009)(15) resulted in that e-marketing was a positive effect on the current and future market performance in terms of participation in knowledge, study of Ahmed Ramadan Tawfik Mohamed (2015)(5) said that e-commerce is an additional finance source for sports authorities.

The researchers made a pilot study, attachment no. (1) through a codified interview for a (12) subjects sample of officials of some sports organizations (clubs and youth centers) including some questions to identify digital economy nature and have to apply in sports organizations. The pilot study resulted in the following responses: 
- $\quad$ Most of the pilot study sample agreed at (75\%:91.66\%) upon the absence of necessary infrastructure of this new ecommerce type in many sports organizations represented in computers, new communication appliances, internet, e-programs and their operating, data bases and market information center.

- The pilot study sample opinions agreed at $(83.33 \%)$ upon that human cadres in sports organizations are not qualified electronically to use such appliances.

- $\quad$ The pilot study sample opinions agreed at (58.33\%) upon none clear future vision of e-marketing for some sports organizations managers.

According to worldwide internet users statistics in the period (2000-2016) as stated in table no. (1) and results and recommendations of some provisions studies, it was clear for researchers how far digital economy is important and in its role in developing organizations aiming at applying the same specially we attend internet and technology age, however the result of pilot study made by the researchers proved low level of technology and e-marketing in sports organizations which made researchers study this subject under the title "Requirements of Applying Digital Economy in Sports Organizations"

\section{Research Objectives:}

This research aims at identifying requirement of applying economy in sports organizations through:

1- Identifying the importance of applying digital economy in sports organization 2- Identifying factors of digital economy in sports organizations

3- Identifying laws and regulations needed for applying digital economy in sports organizations

\section{Research Procedures:}

Used method: the researchers used the survey descriptive method as suitable for the research nature.

\section{Table No. (2)}

Numerical description on the research sample distributed to the pilot study and the main study.

\begin{tabular}{|c|c|c|c|c|c|}
\hline $\begin{array}{l}\text { Research } \\
\text { Community }\end{array}$ & $\begin{array}{l}\text { Research } \\
\text { Community } \\
\text { Groups }\end{array}$ & $\begin{array}{c}\text { Total } \\
\text { Sample }\end{array}$ & $\begin{array}{c}\text { Pilot } \\
\text { Sample }\end{array}$ & $\begin{array}{l}\text { Removed } \\
\text { sample }\end{array}$ & $\begin{array}{l}\text { Main } \\
\text { Sample }\end{array}$ \\
\hline \multicolumn{3}{|c|}{ Assiut Journal For Sport Science Art } & & & \\
\hline
\end{tabular}




\begin{tabular}{|c|c|c|c|c|c|}
\hline \multirow{8}{*}{$\begin{array}{l}\text { (First Group) } \\
\text { Leading and } \\
\text { administrative } \\
\text { cadres } \\
\text { working in } \\
\text { sports field }\end{array}$} & $\begin{array}{l}\text { Leaderships } \\
\text { working in } \\
\text { ministries of } \\
\text { youth and sports }\end{array}$ & 25 & 3 & 1 & 21 \\
\hline & $\begin{array}{l}\text { Members of } \\
\text { Olympic } \\
\text { committee board }\end{array}$ & 3 & - & - & 3 \\
\hline & $\begin{array}{l}\text { Members of } \\
\text { sports leagues } \\
\text { board }\end{array}$ & 18 & 5 & 2 & 11 \\
\hline & $\begin{array}{lr}\begin{array}{l}\text { Members } \\
\text { of } \\
\text { sports }\end{array} & \text { clubs } \\
\text { boards } & \\
\end{array}$ & 24 & 3 & 3 & 18 \\
\hline & $\begin{array}{l}\text { Marketing } \\
\text { Managers } \\
\text { sports clubs }\end{array}$ & 5 & 2 & - & 3 \\
\hline & $\begin{array}{l}\text { Managers of } \\
\text { sports activity in } \\
\text { sports clubs }\end{array}$ & 5 & - & - & 5 \\
\hline & $\begin{array}{l}\text { Youth centers } \\
\text { managers }\end{array}$ & 8 & - & 1 & 7 \\
\hline & Total & 88 & 15 & 8 & 68 \\
\hline \multirow{3}{*}{$\begin{array}{l}\text { Second Group) } \\
\text { Leading and } \\
\text { administrative } \\
\text { cadres in the } \\
\text { field of } \\
\text { investment and } \\
\text { e-commerce }\end{array}$} & $\begin{array}{l}\text { Members of e- } \\
\text { commerce club, } \\
\text { Cairo University }\end{array}$ & 15 & 3 & 1 & 11 \\
\hline & $\begin{array}{ll}\begin{array}{l}\text { Members } \\
\text { chamber } \\
\text { commerce }\end{array} & \begin{array}{l}\text { of } \\
\text { of }\end{array} \\
\end{array}$ & 35 & 3 & 2 & 30 \\
\hline & Total & 50 & 6 & 3 & 41 \\
\hline \multirow[t]{3}{*}{$\begin{array}{l}\text { (Third Group) } \\
\text { Users of sports } \\
\text { authorities } \\
\text { services }\end{array}$} & 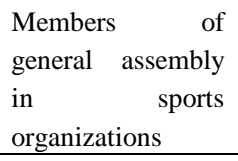 & 45 & 3 & 2 & 30 \\
\hline & $\begin{array}{l}\text { Players and sports } \\
\text { teams in sports } \\
\text { authorities }\end{array}$ & 40 & 3 & 3 & 35 \\
\hline & Total & 85 & 6 & 5 & 65 \\
\hline \multicolumn{2}{|l|}{ Total } & 223 & 27 & 16 & 174 \\
\hline
\end{tabular}

Data Collection Tools:

The researchers used drafter factors and statements questionnaire form to collect the research information then the researcher identified and of questionnaire form as the statements reached (59) main statements and (40) marginal 
statement, then the researcher recommended bi- estimation Thurston balance (Yes - No) to submit experts under the former steps, the form took its primary form attachment No. (2)

Scientific Coefficient of Questionnaire Form:

A. Internal consistency validity

Table (3)

internal consistency coefficient the words of the first axis: the importance of the digital economy in the application of sports institutions $\mathbf{N}=\mathbf{2 7}$

\begin{tabular}{|c|c|c|c|c|c|c|c|}
\hline \multicolumn{2}{|c|}{ The first axis } & \multicolumn{2}{|c|}{ The second axis } & \multicolumn{2}{|c|}{ The second axis } & \multicolumn{2}{|c|}{ The third axis } \\
\hline $\begin{array}{l}\text { No. } \\
\text { phrase }\end{array}$ & $\begin{array}{c}\text { The correlation } \\
\text { coefficient }\end{array}$ & $\begin{array}{c}\text { No. } \\
\text { phrase }\end{array}$ & $\begin{array}{l}\text { The } \\
\text { correlation } \\
\text { coefficient }\end{array}$ & $\begin{array}{l}\text { No. } \\
\text { phrase }\end{array}$ & $\begin{array}{l}\text { The } \\
\text { correlation } \\
\text { coefficient }\end{array}$ & $\begin{array}{c}\text { No. } \\
\text { phrase }\end{array}$ & $\begin{array}{l}\text { The } \\
\text { correlation } \\
\text { coefficient }\end{array}$ \\
\hline 1 & $* * . \vee . \circ$ & $r / 19$ & & $11 / \varepsilon / 19$ & $* * .7 \leq \Gamma$ & $\leq 0$ & $* * ., V Y \leq$ \\
\hline 2 & **. ס ש ד.7 & $1 / 5 / 19$ & & $19 / 5 / 19$ & $* * . . T V \leqslant$ & $\leqslant 7$ & $* * . .7 \leq 7$ \\
\hline 3 & $* * ., V Y T$ & $1 / 1 / \pi / 19$ & $* * . .011$ & $r \cdot / \varepsilon / 19$ & $* * .77$. & $\varepsilon V$ & $* * . \vee \vee r q$ \\
\hline 4 & $* * . .111$ & $r / T / r / 19$ & $* * . T \wedge r$ & r. & $* * \cdot . v \cdot r$ & $\varepsilon \wedge$ & $* * . .7 \vee \wedge$ \\
\hline 5 & $* * .010$ & $r / T / 19$ & & rI & $* * \cdot . v \cdot r$ & $\leq 9$ & **. .า \\
\hline 6 & $* * .701$ & $1 / T / T / 19$ & $* * . .7 \leq 0$ & rr & $* * .09 \wedge$ & 0. & $* * . \vee v 1$ \\
\hline 7 & $* *$. Or & $r / T / T / 19$ & $* * . .77 V$ & r & $* * . .7 \leq 7$ & 01 & **. Tr. \\
\hline 8 & $* * . \vee \vee \leqslant \Lambda$ & $r / 19$ & & $r \leq$ & $* * .779$ & or & $* * .707$ \\
\hline 9 & $* * .099$ & $1 / 1 / 19$ & $* * .7 \leq \Lambda$ & ro & $* * .0 \wedge \wedge$ & or & $* * . V Y r$ \\
\hline 10 & **.TY & $r / T / 19$ & & צד & **.Tा & $0 \leqslant$ & **. \\
\hline 11 & **. Trt & $1 / T / T / 19$ & $* * . T V T$ & TV & $* * .070$ & 00 & **. .770 \\
\hline \multirow{2}{*}{\multicolumn{2}{|c|}{ The second axis }} & $r / T / T / 19$ & $* * .709$ & $\begin{array}{l}r A \\
r q\end{array}$ & $\begin{array}{l}* * . v 17 \\
* * \text {. vor }\end{array}$ & 07 & $* * . \vee \vee q$ \\
\hline & & $r / r / T / 19$ & $* * . .7 \leq 7$ & \multicolumn{2}{|c|}{ The third axis } & or & **. .7т. \\
\hline ir & & $\varepsilon / 19$ & & $r$. & $* * .099$ & & \\
\hline $1 / 14$ & $* * . .091$ & $1 / \varepsilon / 19$ & $* * .$. . & M & **. 7ז9 & & \\
\hline$r / T$ & $* * .7 \leq 7$ & $r / \varepsilon / 19$ & **. v.r & re & $* *, v \cdot v$ & & \\
\hline
\end{tabular}

Follow Table (3)

internal consistency coefficient the words of the first axis: the importance of the digital economy in the application of sports institutions $\mathbf{N}=\mathbf{2 7}$ 


\begin{tabular}{|c|c|c|c|c|c|c|c|}
\hline \multicolumn{2}{|c|}{ The first axis } & \multicolumn{2}{|c|}{ The second axis } & \multicolumn{2}{|c|}{ The second axis } & \multicolumn{2}{|c|}{ The third axis } \\
\hline $\begin{array}{c}\text { No. } \\
\text { phrase }\end{array}$ & $\begin{array}{c}\text { The correlation } \\
\text { coefficient }\end{array}$ & $\begin{array}{c}\text { No. } \\
\text { phrase }\end{array}$ & $\begin{array}{l}\text { The } \\
\text { correlation } \\
\text { coefficient }\end{array}$ & $\begin{array}{c}\text { No. } \\
\text { phrase }\end{array}$ & $\begin{array}{l}\text { The } \\
\text { correlation } \\
\text { coefficient }\end{array}$ & $\begin{array}{c}\text { No. } \\
\text { phrase }\end{array}$ & $\begin{array}{l}\text { The } \\
\text { correlation } \\
\text { coefficient }\end{array}$ \\
\hline$r / T$ & סדז. ש. & $r / \varepsilon / 1 q$ & **. & אי & $* * .770$ & & \\
\hline ir & $* * .09 \leq$ & $\varepsilon / \varepsilon / 19$ & $* * . .7 \vee 1$ & $r \varepsilon$ & $* * . \vee 19$ & & \\
\hline $1 \leq$ & סשד. ש. ** & $0 / \varepsilon / 19$ & **. ONr & ro & $* * ., T \leq 0$ & & \\
\hline 10 & $* * \cdot V I r$ & $\begin{array}{l}7 / \varepsilon / 19 \\
V / \varepsilon / 19\end{array}$ & $\begin{array}{l}* * \cdot . \uparrow \wedge . \\
* * . . \wedge \cdot \wedge\end{array}$ & די & **. Tr. & & \\
\hline 17 & $* * ., V T V$ & & & rv & $* * ., V Y$. & & \\
\hline IV & **. . Tา. & $\Lambda / \varepsilon / 19$ & $* * . \vee \vee 70$ & r & $* * .709$ & & \\
\hline 11 & **. . T & $9 / \varepsilon / 19$ & $* * .094$ & rq & & & \\
\hline 19 & & $1 \cdot / 2 / 19$ & **. צד & $1 / 49$ & $* * .701$ & & \\
\hline $1 / 19$ & & $11 / \varepsilon / 19$ & **. . Tr & $\begin{array}{l}r / r q \\
r / r q\end{array}$ & $\begin{array}{l}* * . . \vee \\
* * .709\end{array}$ & & \\
\hline $1 / 1 / 19$ & $* * . .091$ & $\mid r / \varepsilon / 19$ & $* * . .7 .7$ & $\begin{array}{c}\varepsilon / \Gamma q \\
\varepsilon .\end{array}$ & $\begin{array}{l}* * . V I 1 \\
* * . \text { ONr }\end{array}$ & & \\
\hline$r / 1 / 19$ & $* * ., v 11$ & $1 \pi / \varepsilon / 19$ & $* * \cdot . V \cdot \varepsilon$ & 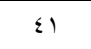 & **.Tr. & & \\
\hline$r / 1 / 19$ & & $1 \leq / \varepsilon / 19$ & $* * . .701$ & $\varepsilon r$ & $* * .701$ & & \\
\hline $1 / 1 / 1 / 19$ & $* * ., V Y \leq$ & $10 / 5 / 19$ & $* * . .7 \leq 0$ & $\varepsilon r$ & **.7ז. וד & & \\
\hline$r / T / 1 / 19$ & **. VYr & $17 / 5 / 19$ & $* * . .779$ & $\varepsilon \varepsilon$ & $* * .79 \vee$ & & \\
\hline$r / \Gamma / 1 / 19$ & $* * .091$ & $1 V / \varepsilon / 19$ & **. & & & & \\
\hline
\end{tabular}

** Significant at the 0.01 level $=0.487$

* Significant at the 0.05 level $=0.381$

Shown in Table No. (3) that the calculated values of correlation coefficients greater than the tabular value at the level of significance (0.01) which shows the sincerity of the internal consistency of the

Table No. (4)

questionnaire phrases axes with the axis to which they belong phrase.

B: Reliability: reliability was found through

- Calculating reliability according to Cronbach Alpha

Cronbach Alpha coefficient for questionnaire factors $\mathrm{N}=\mathbf{2 7}$

\begin{tabular}{c||c|c}
\hline \hline Factors & \multicolumn{2}{|c}{ Cronbach Alpha } \\
& For & For \\
\hline \hline \multirow{2}{*}{ Assiut Journal For Sport Science Arts } & \multicolumn{2}{c}{} \\
&
\end{tabular}


First Factor: The importance of applying digital economy in sports organizations

Second Factor: Bases
"elements" of digital
economy in sports
organizations

First Dimension: Information and communication technology needed for applying digital economy in sports organization

Second Dimension: Ecommerce

Factors Questionnaire

0.728

0.741

0.817

\begin{tabular}{l|l} 
& $\begin{array}{l}\text { Second Dimension: E- } \\
\text { commerce }\end{array}$ \\
\hline &
\end{tabular}

Third Factors: Laws and regulations needed for applying digital economy in sports organization

From table No. (4) It is clear that values of coefficient of reliability of factors and form as a whole are by value greater than (0.817) to prove the form reliability.

Research Application:

After applying the questionnaire form scientific

Table. (5)

The first axis phrases: the importance of the digital economy in the application of sports institutions $\mathrm{N}=174$

\begin{tabular}{|c|c|c|c|c|c|c|c|c|c|}
\hline \multirow{3}{*}{ no } & \multicolumn{6}{|c|}{ Araltkar and the percentage approval to the three research groups } & \multirow{3}{*}{$\begin{array}{c}\text { Kai } 2 \\
\text { between } \\
\text { the } \\
\text { groups } \\
\text { in the } \\
\text { rates of } \\
\text { approval }\end{array}$} & \multirow{2}{*}{\multicolumn{2}{|c|}{$\begin{array}{c}\text { College Search Group } \\
\qquad \mathrm{N}=174\end{array}$}} \\
\hline & \multicolumn{2}{|c|}{$\begin{array}{l}\text { Cadres sports field } \\
\qquad N=68\end{array}$} & \multicolumn{2}{|c|}{$\begin{array}{c}\text { Cadres investment } \\
\text { and electronic } \\
\text { commerce } \\
\mathrm{N}=41\end{array}$} & \multicolumn{2}{|c|}{$\begin{array}{c}\text { The beneficiaries of } \\
\text { the services of sports } \\
\text { bodies } \\
N=65\end{array}$} & & & \\
\hline & Aaltkar & $\begin{array}{c}\text { Percentage } \\
\%\end{array}$ & Aaltkar & $\begin{array}{c}\text { Percentage } \\
\%\end{array}$ & Aaltkar & $\begin{array}{c}\text { Percentage } \\
\%\end{array}$ & & Aaltkar & $\begin{array}{c}\text { Percentage } \\
\%\end{array}$ \\
\hline 1 & r & 94.70 & ro & 10.rV & $0 \wedge$ & N9. r & $\cdot r \cdot$ & 107 & 19.77 \\
\hline 2 & Tr & 91.11 & re & $\mathrm{VA} . .0$ & 07 & 1. 10 & $1 . r$ & 10. & $\Delta T^{\prime}, Y_{1}$ \\
\hline 3 & 7. & $\Lambda \Lambda . r \leq$ & rv & $q \cdot . r \leq$ & or & NV. 79 & $\because \cdot \varepsilon$ & $10 \leqslant$ & 11.01 \\
\hline 4 & 71 & 19.V1 & Tr & $\mathrm{VA} .{ }^{\circ} .0$ & $0 \leqslant$ & גז.ی &.$\Delta r$ & $1 \leq V$ & $\Lambda \leq . \leqslant$ \\
\hline
\end{tabular}

Follow Table. (5)

The first axis phrases: the importance of the digital economy in the application of sports institutions $\mathrm{N}=174$

\begin{tabular}{|c|c|c|c|}
\hline no & Araltkar and the nercentage apnroval to the three research groups & $\begin{array}{c}\begin{array}{c}\text { Kai } 2 \\
\text { between }\end{array} \\
\end{array}$ & College Search Group \\
\hline
\end{tabular}




\begin{tabular}{|c|c|c|c|c|c|c|c|c|c|}
\hline & \multicolumn{2}{|c|}{$\begin{array}{c}\text { Cadres sports field } \\
\qquad N=68\end{array}$} & \multicolumn{2}{|c|}{$\begin{array}{c}\text { Cadres investment and } \\
\text { electronic commerce } \\
\mathrm{N}=41\end{array}$} & \multicolumn{2}{|c|}{$\begin{array}{c}\text { The beneficiaries of the } \\
\text { services of sports bodies } \\
\text { N=65 }\end{array}$} & \multirow{2}{*}{$\begin{array}{c}\text { the } \\
\text { groups } \\
\text { in the } \\
\text { rates of } \\
\text { approval }\end{array}$} & \multicolumn{2}{|c|}{$\mathrm{N}=174$} \\
\hline & Aaltkar & $\begin{array}{c}\text { Percentage } \\
\%\end{array}$ & Aaltkar & $\begin{array}{c}\text { Percentage } \\
\%\end{array}$ & Aaltkar & $\begin{array}{c}\text { Percentage } \\
\%\end{array}$ & & Aaltkar & $\begin{array}{c}\text { Percentage } \\
\%\end{array}$ \\
\hline 5 & 01 & 10.19 & $r$. & VT.IV & 07 & 17.10 & 1.49 & $1 \leq \varepsilon$ & Ar.VT \\
\hline 6 & 09 & 1..V7 & Tr & $\wedge \cdot . \leqslant q$ & or & $11.0 \leqslant$ & $\cdot r V$ & $1 \leq 0$ & זr.זה \\
\hline 7 & Tז & 94.70 & ro & 10.rV & or & $\wedge \cdot .$. & $\cdot 9 \varepsilon$ & 10. & N., r) \\
\hline 8 & ov & Ar.Ar & ו & vo.71 & $0 \leqslant$ & גז.A & .01 & $1 \leq r$ & 11.71 \\
\hline 9 & 7. & $M \Lambda . r \leq$ & rᄉ & $9 Y .71$ & or & $\wedge .$. & .90 & 10. & 人., Y \\
\hline 10 & 01 & 10.19 & צו & $\wedge \vee . \wedge$. & 07 & 17.10 & $\because \cdot \varepsilon$ & 10. & AT.YI \\
\hline 11 & 71 & ง . . & $r \leq$ & Ar.qT & ov & NV. 79 & $\cdot r_{\lambda}$ & lor & AV.ru \\
\hline
\end{tabular}

Kai significant square at $0.05=5.99$

Shown in Table No. (5)As the first group's opinions were that leading cadres in sports "at high percentages of agreement on the importance of digital economy in sports organizations specially statements number (1) (2) (7) indicating that digital economy is a tool of change and development and a strategic importance in sports organizations, digital economy assists the sports organization to avail and develop investments and capitals to support smart ideas, digital economy relates to digital technology that made sports organization avoid expanding, transferring and creating information, distribution and marketing whose agreement percentage reached $(92.65 \%)$ (91.18\%)

$(92.65 \%)$ respectively.

\section{Fatih Megahdy} (2007)(12) confirms that digital economy is the economy depends on using technology, accordingly it is also know by internet economy, network economy or new economy, accordingly it is said that knowledge is one of the most important new organization bases specially that work under digital economy.

While the second group's opinions "cadres of investment and e-commerce about statements No. (3) (9) (10) of that digital economy depending on new means of communication

characterized by quick performance, direct response and low costs of obtaining sports services and activities digital economy enables sports organization to increase its ability to international competition in offering sports services and may contribute in achieving all commercial deals via internet at high agreement percentage $(90.24 \%)(92.68 \%)$ $(87.80 \%)$

\section{Assiut Journal For Sport Science Arts}


This what was recommended by study of Omar Azazzy (2008) (32) of the importance of having strategic plans to establish scientific knowledge community focusing on the role of this knowledge and availing suitable environment for activation and giving increase including securing the new technology environment as a whole.

The third group of users' opinion about statements no. (1) (11) (3) related to the fact that digital economy depending on new communication means is characterized by quick performance, direct response and low costs of obtaining sports services and activities whose agreement percentages reached $(89.23 \%) \quad(87.69 \%)$ $(87.69 \%)$ respectively.

Accordingly the study of Rasha Dorid Hanna and Saar Ahmed Saadon El Seman (2015) (33) confirm that information and communication technology may increase work efficiency through its components of (tools and equipments, programs, communications, human resources) from organizational performance speed.

\section{Table. (6)}

The scend axis phrases: The foundations of the digital economy in the sports institutions The first dimension: information and communication necessary for the application of the digital economy sports institutions Technology $\mathrm{N}=174$

\begin{tabular}{|c|c|c|c|c|c|c|c|c|c|}
\hline \multirow{3}{*}{ no } & \multicolumn{6}{|c|}{ Araltkar and the percentage approval to the three research groups } & \multirow{3}{*}{$\begin{array}{c}\text { Kai } 2 \\
\text { between } \\
\text { the } \\
\text { groups } \\
\text { in the } \\
\text { rates of } \\
\text { approval }\end{array}$} & \multirow{2}{*}{\multicolumn{2}{|c|}{$\begin{array}{l}\text { College Search Group } \\
\qquad \mathrm{N}=174\end{array}$}} \\
\hline & \multicolumn{2}{|c|}{$\begin{array}{l}\text { Cadres sports field } \\
\qquad N=68\end{array}$} & \multicolumn{2}{|c|}{$\begin{array}{l}\text { Cadres investment and } \\
\text { electronic commerce } \\
\mathrm{N}=41\end{array}$} & \multicolumn{2}{|c|}{$\begin{array}{l}\text { The beneficiaries of the } \\
\text { services of sports bodies } \\
\mathrm{N}=65\end{array}$} & & & \\
\hline & Aaltkar & $\begin{array}{c}\text { Percentage } \\
\%\end{array}$ & Aaltkar & $\begin{array}{c}\text { Percentage } \\
\%\end{array}$ & Aaltkar & $\begin{array}{c}\text { Percentage } \\
\%\end{array}$ & & Aaltkar & $\begin{array}{c}\text { Percentage } \\
\%\end{array}$ \\
\hline IT & & & & & & & & & \\
\hline $1 / 14$ & 70 & 90.09 & r & $V \wedge .0$ & זי & 97.94 & Y. $\leqslant 7$ & 17. & 91.90 \\
\hline$T / 1 \mathrm{~T}$ & $\overline{T H}$ & 91.11 & $\Gamma$. & VT.IV & 71 & $94 . \wedge 0$ & r. $9 \leqslant$ & 104 & Av.9T \\
\hline$T / 1 \mathrm{~T}$ & 7. & $\Lambda \wedge . Y \leq$ & T & vo.TI & $\pi r$ & $90 . r \wedge$ & T.r. & 104 & NV.qr \\
\hline$\pi$ & 07 & ס ז.rA & $r$. & VT.IV & 01 & 19.rT & 1.09 & $1 \leq \varepsilon$ & AY.VT \\
\hline $1 \varepsilon$ & ov & גז.Ar & rr & $V \wedge . .0$ & 00 & Aะ.TY & $\cdot r$ & $1 \leq \varepsilon$ & NY.VT \\
\hline
\end{tabular}

Follow Table. (6)

The scend axis phrases: The foundations of the digital economy in the sports institutions The first dimension: information and communication necessary for the application of the digital economy sports institutions Technology $N=174$ 


\begin{tabular}{|c|c|c|c|c|c|c|c|c|c|}
\hline \multirow{3}{*}{ no } & \multicolumn{6}{|c|}{ Araltkar and the percentage approval to the three research groups } & \multirow{3}{*}{$\begin{array}{c}\text { Kai } 2 \\
\text { between } \\
\text { the } \\
\text { groups } \\
\text { in the } \\
\text { rates of } \\
\text { approval }\end{array}$} & \multirow{2}{*}{\multicolumn{2}{|c|}{$\begin{array}{l}\text { College Search Group } \\
\qquad \mathrm{N}=174\end{array}$}} \\
\hline & \multicolumn{2}{|c|}{$\begin{array}{l}\text { Cadres sports field } \\
\qquad \mathrm{N}=68\end{array}$} & \multicolumn{2}{|c|}{$\begin{array}{c}\text { Cadres investment and } \\
\text { electronic commerce } \\
\mathrm{N}=41\end{array}$} & \multicolumn{2}{|c|}{$\begin{array}{c}\text { The beneficiaries of the } \\
\text { services of sports bodies } \\
N=65\end{array}$} & & & \\
\hline & Aaltkar & $\begin{array}{c}\text { Percentage } \\
\%\end{array}$ & Aaltkar & $\begin{array}{c}\text { Percentage } \\
\%\end{array}$ & Aaltkar & $\begin{array}{c}\text { Percentage } \\
\%\end{array}$ & & Aaltkar & $\begin{array}{c}\text { Percentage } \\
\%\end{array}$ \\
\hline 10 & or & $V 7 . \leqslant V$ & rq & $v \cdot . v r$ & o. & V7.9Y & $\cdot r$ & M & Vo. Yq \\
\hline 17 & $0 \leqslant$ & $\vee 9 . \leqslant 1$ & $r \wedge$ & 71.49 & or & $\wedge \cdot . \cdots$ & 1.10 & $1 \pi \varepsilon$ & $V V . \cdot 1$ \\
\hline iv & or & $\vee \vee .9 \leq$ & r. & VT.IV & 07 & 17.10 & 1.99 & 179 & $\vee 9 . \wedge 9$ \\
\hline 11 & 09 & NT.V7 & r & $v \wedge .0$ & or & NV.79 & $.7 V$ & $1 \leqslant 1$ & 10.7 \\
\hline 19 & & & & & & & & & \\
\hline \multirow{6}{*}{$19 / 1$} & Tr & 91.11 & Tr & $\wedge . \leq q$ & 07 & 17.10 & $.7 V$ & 101 & 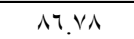 \\
\hline & or & $V T . \leqslant V$ & rq & $v \cdot . V r$ & 01 & $\vee \wedge . \leqslant 7$ & $\cdot \varepsilon r$ & TrT & Vo.AT \\
\hline & & & & & & & & & \\
\hline & 01 & vo... & r. & VT.IV & 00 & ᄉะ.T & $\cdot 9 V$ & דאו & VA. 17 \\
\hline & 00 & $\wedge . \wedge \Lambda$ & rq & $V \cdot . V T$ & $0 \leqslant$ & ^r.A & 1.11 & IT人 & Vq.r \\
\hline & 0. & VT.or & rA & 71.49 & or & $\wedge .$. & .94 & IT. & $v \leqslant . V I$ \\
\hline \multirow{4}{*}{$19 / 2$} & 07 & ס.זrג & ro & 10.rV & or & AV. 79 & $\because$ IV & $1 \leq \Lambda$ & 10.7 \\
\hline & or & גז.Ar & $r$. & VT.IV & $0 \leqslant$ & ᄉr. & $\cdot \wedge \Lambda$ & $1 \leq 1$ & $11 . r$ \\
\hline & or & $V T . \leqslant V$ & rq & $v \cdot . V r$ & 01 & $\vee \wedge . \leqslant Y$ &.$\leqslant r$ & ITr & VO.AT \\
\hline & or & $V 7 . \leqslant V$ & Tr & $\nabla \wedge .00$ & or & $\wedge . . \cdots$ & $\because \wedge$ & 157 & $\vee \wedge .17$ \\
\hline \multirow{4}{*}{$19 / 3$} & 0. & VT.or & זr & $\wedge . \leq 9$ & 07 & 17.10 & $1 \ldots$ & 1149 & $\vee १ . \wedge 9$ \\
\hline & 09 & Aт.VT & $\Gamma \varepsilon$ & N.qT & or & NV.79 & .10 & 10. & AT.Y \\
\hline & 00 & $\wedge . . \wedge \Lambda$ & rq & $V \cdot . V r$ & 00 & $\wedge \varepsilon . T Y$ & 1.4 & 1149 & $\vee १ . \wedge 9$ \\
\hline & 01 & 10. r9 & r & $\vee \wedge .0$ & or & $11.0 \leqslant$ & . & $1 \leqslant r$ & Ar.lA \\
\hline
\end{tabular}

Follow Table. (6)

The scend axis phrases: The foundations of the digital economy in the sports institutions The first dimension: information and communication necessary for the application of the digital economy sports institutions Technology $N=174$

Assiut Journal For Sport Science Arts 


\begin{tabular}{|c|c|c|c|c|c|c|c|c|c|}
\hline \multirow{3}{*}{ no } & \multicolumn{6}{|c|}{ Araltkar and the percentage approval to the three research groups } & \multirow{3}{*}{$\begin{array}{c}\text { Kai } 2 \\
\text { between } \\
\text { the } \\
\text { groups } \\
\text { in the } \\
\text { rates of } \\
\text { approval }\end{array}$} & \multirow{2}{*}{\multicolumn{2}{|c|}{$\begin{array}{c}\text { College Search } \\
\text { Group } \\
\text { N=174 }\end{array}$}} \\
\hline & \multicolumn{2}{|c|}{$\begin{array}{l}\text { Cadres sports field } \\
\qquad N=68\end{array}$} & \multicolumn{2}{|c|}{$\begin{array}{c}\text { Cadres investment } \\
\text { and electronic } \\
\text { commerce } \\
\mathrm{N}=41\end{array}$} & \multicolumn{2}{|c|}{$\begin{array}{c}\text { The beneficiaries of } \\
\text { the services of sports } \\
\text { bodies } \\
N=65\end{array}$} & & & \\
\hline & Aaltkar & $\begin{array}{c}\text { Percentage } \\
\%\end{array}$ & Aaltkar & $\begin{array}{c}\text { Percentage } \\
\%\end{array}$ & Aaltkar & $\begin{array}{c}\text { Percentage } \\
\%\end{array}$ & & Aaltkar & $\begin{array}{c}\text { Percentage } \\
\%\end{array}$ \\
\hline \multirow{20}{*}{$19 / 4$} & $0 \leq$ & $\vee 9 . \leqslant 1$ & rr & $\vee \wedge . \cdot \bullet$ & $\Delta \wedge$ & $\wedge 9 . \mathrm{rr}^{\mathrm{r}}$ & $\because 91$ & $1 \leq \leq$ & Ar.V५ \\
\hline & or & $V ५ . \leqslant V$ & 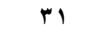 & v०.71 & ov & $\wedge \vee .79$ & $1.1 \leqslant$ & $1 \leq$ & $\Lambda \cdot . \leqslant 7$ \\
\hline & 01 & $v \bullet . \cdots$ & rq & $v \cdot . v r$ & $0 \leqslant$ & $\Lambda r . \wedge$ & $1 . \cdot r$ & $1 T \varepsilon$ & $v v_{.} \cdot 1$ \\
\hline & $\leq 7$ & $7 V .70$ & $r \wedge$ & $71 . \times 9$ & o. & $V 7.9 Y$ & $\because V^{7}$ & $1 Y \leq$ & VI.YY \\
\hline & or & $V \Psi . \leqslant V$ & ro & $\Lambda 0 . r v$ & 00 & $\Lambda \leq .7 Y$ & $\because .09$ & $1 \leqslant Y$ & 11.71 \\
\hline & 01 & $v_{0} . .$. & $r r$ & $\Lambda \cdot . \leqslant 9$ & or & $\Lambda \cdot . \cdots$ & $\because r \leq$ & 174 & $\vee \wedge .17$ \\
\hline & $\leqslant 9$ & VY. ${ }^{\top} T$ & $r \wedge$ & $\checkmark 1 . Y q$ & $0 \leqslant$ & Ar.A & 1.09 & $|r|$ & vo.rq \\
\hline & or & $V V . q \leq$ & ry & $\wedge \vee . \wedge$. & $O V$ & AV. 79 &.$\vee V 4$ & $1 \leq 7$ & Ar.q1 \\
\hline & $0 \leq$ & $v q . \leqslant 1$ & $r 1$ & $v 0.71$ & $\leq 9$ & $v 0 . r \Lambda$ & $\because 1 T$ & 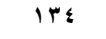 & $v v_{.} \cdot 1$ \\
\hline & $\leqslant \Lambda$ & $v \cdot .09$ & $r$. & VT.IV & 01 & $\vee \wedge . \leqslant 4$ & 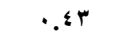 & $1 \times 9$ & $V \leq .1 \leq$ \\
\hline & $\leqslant V$ & 79.14 & rq & $v \cdot . v r$ & or & $\wedge . . \cdots$ & $\cdot .9 \leq$ & $1 Y \Lambda$ & VT.0T \\
\hline & $\leqslant r$ & 11.87 & $r V$ & $10 . \wedge 0$ & $\leqslant 9$ & vo.rA & $1 . \leqslant \leq$ & 111 & TV.AY \\
\hline & $\leqslant 0$ & 74.11 & $r$. & VY.IV & 0. & $V 7.9 Y$ & $\cdot{ }^{\wedge \mu}$ & iro & $\vee \backslash . \wedge \leq$ \\
\hline & $0 \leq$ & $v q . \leqslant 1$ & $r_{1}$ & $v 0.71$ & or & $11.0 \leq$ &.$r r$ & $1 \mathrm{r}$ & V৭.r. \\
\hline & 01 & $v_{0} .$. & $r$. & Vr.IV & 0. & $V 7.9 Y$ & $\because 99$ & $|r|$ & vo.rq \\
\hline & 07 & ט.r. & $r \leq$ & Ar.qr & 07 & 17.10 & $\because 1$. & $1 \leq 7$ & Ar.q1 \\
\hline & 00 & $\wedge \cdot . \wedge \wedge$ & $r r$ & $1 \cdot . \leqslant 9$ & $\Delta V$ & AV. 79 & $\because \varepsilon$ & $1 \leq 0$ & Nr.rr \\
\hline & $\leqslant 0$ & 77.11 & rq & $v \cdot . v r$ & 01 & $\vee \wedge . \leqslant 4$ & $1 . \cdot v$ & 1ro & $\vee \backslash . \wedge \varepsilon$ \\
\hline & $\leqslant V$ & 79.14 & rq & $v \cdot . v r$ & 01 & $\vee \wedge . \leqslant \checkmark$ & .79 & IrV & VY.q9 \\
\hline & $\varepsilon$ & $\Delta \wedge . \wedge Y$ & $r V$ & $10 . \wedge 0$ & $\leq V$ & VY.r. & $1 . r q$ & $11 \leq$ & 10.04 \\
\hline
\end{tabular}

\section{Kai significant square at $0.05=5.99$}

As opinions of the first group of cadres working the athletic field and the second group of cadres working in ecommerce agreed at high percentages on statement no. (12) Related to the fact that information and communication technology in digital communication networks are one of the most important bases of digital economy in sports organization at high percentage between (88.24:96.92\%).

This agrees with what was recommended by study of Mohamed

Mahmoud 
Abdallah Youssef (30) of importance of holding conferences and seminars to discuss updates of e-commerce system and compile a national plan to narrow digital and technological gap between Egypt and other countries having similar economic circumstances and fulfilling main requirements of technology development and coordination between different authorities concerning about technology development to push national economy.

As opinions of the third group of users of sports organizations services agreed upon the student No. (19/4/8) (87.80\%).

As results of study of (Eleutherios, Dimitries) (2001) (10) confirmed difficulties facing e-stores, measuring clients' satisfaction and there are social difficulties accompanied applying ecommerce in Greece including non obtaining client's reaction through e-mails.

Statement No. (19/4/20) stating that additional services like mobile phones and downloading call tones related to sports games and sports sites shall have all languages and availing free call to users at lowest agreement percentage between the whole research sample opinions $(65.52 \%)$.

These results agree with results of study of Islam Maamoun Hussein Maamoun (2011) (20) that confirmed a clear decrease in percentage of e-commerce use in Arabic for many reasons including lack of enough Arabic sites and lack of a developed e-payment system in the Arab world to limit economic activities dealing in e-commerce in Arabic.

Table. (7)

the second axis: the pillars of the digital economy in the sports institutions (the second dimension: E-Commerce) $\mathrm{N}=174$

\begin{tabular}{|c|c|c|c|c|c|}
\hline \multirow[b]{2}{*}{ no } & \multicolumn{3}{|c|}{ Araltkar and the percentage approval to the three research groups } & \multirow{2}{*}{$\begin{array}{l}\text { Kai } 2 \\
\text { between } \\
\text { the } \\
\text { groups } \\
\text { in the }\end{array}$} & \multirow{2}{*}{$\begin{array}{l}\text { College Search } \\
\text { Group } \\
\mathrm{N}=174\end{array}$} \\
\hline & $\begin{array}{l}\text { Cadres sports field } \\
\qquad \mathrm{N}=68\end{array}$ & $\begin{array}{l}\text { Cadres investment } \\
\text { and electronic } \\
\text { commerce } \\
\mathrm{N}=41\end{array}$ & $\begin{array}{c}\text { The beneficiaries of } \\
\text { the services of sports } \\
\text { bodies } \\
\mathrm{N}=65\end{array}$ & & \\
\hline
\end{tabular}

Assiut Journal For Sport Science Arts 


\begin{tabular}{|c|c|c|c|c|c|c|c|c|c|}
\hline & Aaltkar & $\begin{array}{c}\text { Percentage } \\
\%\end{array}$ & Aaltkar & $\begin{array}{c}\text { Percentage } \\
\%\end{array}$ & Aaltkar & $\begin{array}{c}\text { Percentage } \\
\%\end{array}$ & $\begin{array}{l}\text { rates of } \\
\text { approval }\end{array}$ & Aaltkar & $\begin{array}{c}\text { Percentage } \\
\%\end{array}$ \\
\hline$r \cdot$ & ov & Ar.Ar & r & $V \wedge . .0$ & or & $\Lambda \cdot . \cdots$ & $\cdot r_{1}$ & $1 \leq 1$ & $11 . r$ \\
\hline rI & or & $V \vee .9 \leq$ & $r$. & VT.IV & or & 1).0 & $\because \leqslant 0$ & 1147 & VA. 17 \\
\hline YY & $0 \leqslant$ & $\vee q . \leqslant 1$ & M & vo.71 & 00 & AE. Tr & .01 & $1 \varepsilon$. & $A \cdot . \leqslant 7$ \\
\hline Tr & ov & $\Lambda r . \wedge r$ & Tr & $\vee \wedge . .0$ & or & $\wedge . .$. & $\cdot\left(r^{\prime}\right.$ & $1 \leq 1$ & $\Lambda ! . r$ \\
\hline$T \leq$ & Tr & 91.11 & ro & 10.rv & 7. & QT.r. & וr & $10 \mathrm{~V}$ & $q . . r T$ \\
\hline ro & $0 \wedge$ & 10.19 & $r$. & VT.IV & 09 & $q . . V V$ & 1.90 & $1 \leq V$ & $\Lambda \leq . \leqslant$ \\
\hline rT & $0 \leqslant$ & $\vee q . \leqslant 1$ & rr & $V \wedge . .0$ & $0 \wedge$ & 19.rT & .91 & $1 \leq \varepsilon$ & Ar.VT \\
\hline YV & 09 & 1..V & 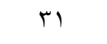 & vo.7l & OV & NV. 79 & $1 . \cdot 1$ & $1 \leqslant V$ & $\lambda \varepsilon . \leqslant \wedge$ \\
\hline rA & 7. & $\Lambda \Lambda . Y \leq$ & $r \varepsilon$ & Ar.qT & 7. & 94.4 & $\because 0$. & $10 \varepsilon$ & 11.01 \\
\hline rq & זד & 94.70 & $r \varepsilon$ & Ar.qT & 71 & 94.10 & $\cdot \wedge$ & 101 & $9 \cdot . \wedge$. \\
\hline$r \cdot$ & 7. & $\wedge \wedge . Y \leq$ & $r \leq$ & Ar.qT & 7. & 94.4 & $\because 0$. & $10 \leqslant$ & $1 \wedge .01$ \\
\hline M & ov & $\wedge r . \wedge r$ & rq & $V \cdot . V T$ & $0 \leqslant$ & $\wedge r . \wedge$ & 1.14 & $1 \leq$. & $1 \cdot . \leqslant 7$ \\
\hline Tr & 07 & NT.ro & $r \wedge$ & 71.49 & 00 & Aะ.TY & 1.99 & 149 & $\vee 9 . \wedge 9$ \\
\hline Tr & 01 & 10. . 9 & Tr & $A \cdot . \leq 9$ & or & $1) .0 \leqslant$ & .10 & $1 \leq \varepsilon$ & Ar.VT \\
\hline$r \varepsilon$ & 0. & Vr.or & $r \wedge$ & 71.49 & $\leq 9$ & vo.ru &.$r V$ & ITV & VY. 99 \\
\hline ro & 09 & ᄉ५. Vฯ & M & $v 0.71$ & ov & AV. 79 & $1 . \cdot 1$ & $1 \leqslant V$ & $\Lambda \varepsilon . \leqslant \Lambda$ \\
\hline ry & 01 & vo... & rr & $V \Lambda .0$ & 01 & $\vee \wedge . \leqslant 7$ & $\because 99$ & $1 \pi \varepsilon$ & $V V_{.}+1$ \\
\hline TV & $\leqslant 9$ & $V Y .{ }^{\top} T$ & rq & $V \cdot . V T$ & $\varepsilon r$ & $T \Sigma .7 Y$ & $\because \leqslant 7$ & IT. & $7 \wedge .9 V$ \\
\hline rᄉ & Tr & 91.11 & rq & $V \cdot . V r$ & $\varepsilon r$ & 77.10 & $\varepsilon . T V$ & $1 \pi \varepsilon$ & $V V_{.} \cdot 1$ \\
\hline \multicolumn{10}{|l|}{ rq } \\
\hline $1 / 49$ & זד & 94.70 & YV & 70.10 & $\leq 0$ & $79 . \mathrm{KT}$ & 0.71 & 1 To & VV.09 \\
\hline$r / r q$ & $0 \wedge$ & 10. 19 & rq & $V \cdot . V r$ & $\leqslant 7$ & $V \cdot . V V$ & $1 . \wedge \mathrm{V}$ & זrו & $V 7 . \leqslant \varepsilon$ \\
\hline$r / r q$ & 07 & NT.ro & $r \wedge$ & 71.49 & $\leqslant V$ & VY.rI & 1.21 & |r| & Vo.rq \\
\hline$\varepsilon / \Gamma q$ & 00 & $\wedge \cdot . \wedge \wedge$ & $r T$ & $\pi$ r. & $\varepsilon \wedge$ & Vr.Ao & r. Kr & 1199 & $V \leq .1 \leq$ \\
\hline$\varepsilon$. & or & $V \tau . \leqslant V$ & $r$. & VT.IV & 01 & $V \wedge . \leqslant 7$ & .19 & Trו & $V T . \leqslant \leq$ \\
\hline \&1 & $\leqslant \wedge$ & $v . .09$ & $r \wedge$ & $7 \wedge . Y 9$ & or & $\wedge .$. & 1.0 & $1 Y \Lambda$ & $V T .07$ \\
\hline$\sum r$ & ov & Ar.Ar & Tr & $V \wedge .00$ & ov & AV. 79 & $.0 \mathrm{~V}$ & $1 \leq 7$ & Ar.q1 \\
\hline$\varepsilon r$ & $\leqslant 0$ & 77.11 & YV & 70.10 & $\leqslant 9$ & vo.ru & $\cdot .10$ & $|Y|$ & $79.0 \leq$ \\
\hline$\varepsilon \varepsilon$ & $\varepsilon \lambda$ & $v \cdot .09$ & $r \wedge$ & 71.49 & $\varepsilon r$ & $T \varepsilon . T Y$ & $\cdot r V$ & 111 & $T V . A Y$ \\
\hline
\end{tabular}

Kai significant square at $0.05=5.99$

From table No. (7) It

was clear that the three research groups opinions agreed upon all statements of the factor at high percentage specially statement No. (24) Of using e-marketing as a new method of supporting sports organizations as agreement percentage were $(85.37 \%)$ (91.18\%) (92.31\%).

Such results agree with results of study of Mohamed Ezzat Ahmed (2013) 
confirmed that e-marketing confirms e-activity in sports clubs and achieve the competitive advantage and a strategic status among clubs.

Such studies also agree with recommendations of study of Sarwat El Sayed Ali El Iraqi (2009) (37) the necessity of focusing on e-commerce and emarketing by sports officials in general and sports clubs in particular and compiling a clear strategy about using ecommerce in the field of sports marketing.

Also statement No. (29) Related to availability of trust and e-information security to avoid losing any information and reaching the ideal limit of securing commercial and financial deals of e-marketing achieved high agreement percentage among the research sample groups' opinions $\begin{array}{lll}(82.93 \%) & (92.65 \%) & (93.85 \%)\end{array}$ respectively.

Under the above results, results of study of Mohamed Bo Shoar Harariy and Omar Aboud (2007) (27) that ecommerce needs a strong communication network free from defects in addition to the need of banks participation in type of trade and accepting epayment system via internet and companies adopting ecommerce shall consider internationally certified protection system and that purchaser and seller shall contribute in credit cards system or any other system allowing e-payment and all shall be connected to internet.

By looking into statement No. (30) Indicating privacy, secrecy and maintaining secrecy of information allowed to be used by sports organization and identifying time of their use, the research sample groups' opinions agreement ranges as follows $(82.93 \%) \quad(88.24 \%)$ $(92.31 \%)$.

This what was confirmed by study of Ahmed Abdallah Al Awady (2010) (3) low awareness of e-deals importance in terms of availing time and including all potential markets and consumers worldwide and lack of secrecy, safety and trust in e-commerce dealers due to Arab world disability to control communication technology and internet.

\section{Table (8)}


redundancy and the percentage of approval of the research sample on the third axis: the laws and regulations necessary for the application of the digital economy sports institutions phrases $\mathrm{N}=174$

\begin{tabular}{|c|c|c|c|c|c|c|c|c|c|}
\hline \multirow{3}{*}{ no } & \multicolumn{6}{|c|}{ Araltkar and the percentage approval to the three research groups } & \multirow{3}{*}{$\begin{array}{l}\text { Kai } 2 \\
\text { between } \\
\text { the } \\
\text { groups } \\
\text { in the } \\
\text { rates of } \\
\text { approval }\end{array}$} & \multirow{2}{*}{\multicolumn{2}{|c|}{$\begin{array}{l}\text { College Search } \\
\text { Group }\end{array}$}} \\
\hline & \multicolumn{2}{|c|}{$\begin{array}{l}\text { Cadres sports field } \\
\qquad N=68\end{array}$} & \multicolumn{2}{|c|}{$\begin{array}{c}\text { Cadres investment } \\
\text { and electronic } \\
\text { commerce } \\
\mathrm{N}=41\end{array}$} & \multicolumn{2}{|c|}{$\begin{array}{l}\text { The beneficiaries of } \\
\text { the services of sports } \\
\text { bodies } \\
\mathrm{N}=65\end{array}$} & & & \\
\hline & Aaltkar & $\begin{array}{c}\text { Percentage } \\
\%\end{array}$ & Aaltkar & $\begin{array}{c}\text { Percentage } \\
\%\end{array}$ & Aaltkar & $\begin{array}{c}\text { Percentage } \\
\%\end{array}$ & & Aaltkar & $\begin{array}{r}\text { Percentage } \\
\%\end{array}$ \\
\hline «0 & or & $V 7 . \leqslant V$ & rt & $\vee \wedge .0$ & 07 & 17.10 & $.7 \mathrm{~V}$ & $1 \leq$. & $\wedge \cdot . \leqslant 7$ \\
\hline$\sum 7$ & $\varepsilon \wedge$ & $v \cdot .09$ & 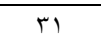 & vo.TI & $0 \leqslant$ & Ar. & $1 . r$ & rra & $V 7 . \leqslant \varepsilon$ \\
\hline$\sum V$ & 0. & vr.or & $r$ r. & VT.IV & or & $11.0 \leq$ & .09 & rr & $V T . \leqslant \varepsilon$ \\
\hline$\varepsilon \wedge$ & $\varepsilon$. & $0 \wedge . \wedge Y$ & $r V$ & 10.10 & $\varepsilon r$ & 77.10 & $.0 \leqslant$ & 11. & זr.rT \\
\hline$\varepsilon 9$ & 01 & vo... & זr & $\Lambda . \leqslant q$ & ov & NV.79 & $1 \ldots$ & $1 \leq 1$ & $11 . \cdot r$ \\
\hline 0. & 7. & $\Lambda \Lambda . Y \leq$ & rT & $v \wedge .0$ & 01 & 19.rT & .9. & 10. & $\Delta, .{ }^{\prime}$ \\
\hline 01 & $0 \leqslant$ & Vq. $\leqslant 1$ & $r \varepsilon$ & אr.qr & ov & AV. 79 & 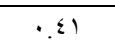 & $1 \leqslant 0$ & זr.זה \\
\hline or & 01 & vo... & rq & $v \cdot . v r$ & 00 & Aะ.Tr & $1 . r r$ & 1To & $V V .09$ \\
\hline or & 00 & $\wedge \cdot \wedge \wedge$ & rr & $v \wedge . .0$ & 01 & $\vee \wedge . \leqslant \tau$ & $\because+7$ & $1 \% \Lambda$ & Vq.r \\
\hline $0 \leqslant$ & $0 \leqslant$ & $\vee q . \leqslant 1$ & M & vo.7I & 0. & $V 7.9 T$ & .1 & 1ro & $V V .09$ \\
\hline 00 & 01 & vo... & rq & $v \cdot . v r$ & $\leq 9$ & vo.rs &. .11 & 1199 & $V \leq .1 \leqslant$ \\
\hline 07 & 71 & $\wedge 9 . \vee 1$ & rᄉ & $7 \wedge .9^{\prime}$ & or & $\Lambda .$. & r.q. & $1 \leq 1$ & $\Lambda 1 . r$ \\
\hline OV & 09 & $\wedge \uparrow . \vee 4$ & Tr & $1 \cdot . \leq q$ & or & $11.0 \leqslant$ & $\cdot r V$ & $1 \leq 0$ & זיזה \\
\hline
\end{tabular}

Kai significant square at $0.05=5.99$

As the statement No. (50) Related to availing legal mechanics for protection intellectual property regarding websites information was ranked the first in percentages of agreement between research groups' opinions that reached (86.21\%).

Both researchers agree with such results as confirmed by study of Islam Mamoun Hussein (2011) (20) of the necessity of establishing e- commerce sites in Arabic through using looking for financial sources suitable for ecommerce projects as well as focusing on rules of rights of intellectual property due to what is published in.

Also statement No. (57), $(89.71 \%)$ referring to sports organization's adoption of work depending on information and knowledge as such two factors are the basis of obtaining a competitive 
advantage in the age of digital economy.

Accordingly, results of study of Haitham Salman Abdallah (2005) (15) confirms that information infrastructure in Gulf cooperation council states couldn't understand ecommerce field in general except the united Arab emirates that developed via using e-commerce in its commercial deals.

This is confirmed by study of Ahmed Elsayed Taha El Kordy (2014) (6) of existence of some risks know by e-shoppers effecting decision of purchasing some endurable goods via internet (product performance information - alternative opportunities) there are some risks unaffecting the internet purchase decision.

But opinions of the second group, cadres working in the field of e-commerce, the highest agreement percentage was on statement No. (51) Of passing laws organizing information circulation and information and international network security organization and reached $(82.93 \%)$.

Under the above results, study of Mohamed Khodry (28) recommended the importance of developing legislations and security services to protect information and developing e-commerce such as e-signature and legalization, there are successful Arab trials represented in Dubai internet city in addition to urging companies to develop websites (in Arabic and foreign language) and developing the use of this network in interaction between the company, its clients and peers to know activity and participate in.

\section{Conclusions}

Based on the above findings the researcher to the conclusions:

- "The digital economy is a tool for change and development and strategic necessity in sports institutions.

- Digital Economy helps sports institution in the provision and development of investments and the heads of funds for supporting the the smart ideas.

- The use of electronic marketing is considered one of modern methods to support sports institutions.

- The level of technology in enterprises is low due to the limited availability of 
computers and software for internet

- To build a sports institutions work based on information and knowledge are the basis for obtaining a competitive advantage in the era of the digital economy. "

Recommendations:

Based on previous findings, the researchers recommend sports institutions and stakeholders to sports officials, including the following:

- all means of modern technology with various sporting institutions to provide

- The need to the rehabilitation cadres Responsible for the marketing of sports institutions electronically.

- The need to provide legal mechanisms for the protection of intellectual property with displays through the websites of Information

- The need to establish ecommerce sites in Arabic

- develop a clear landmarks on how to use e-commerce in the field of sports marketing strategy.

\section{References}

1. Abd al-Majid al-Rifai (2002), the Arabs in front intersections of time and ideology and Development, Dar Al-Fikr, Damascus.
2. Abdullah Moussa

Alqam (2013): the digital economy (finance and economy (Faisal Islamic Bank of Sudan, Issue 72. Sudan

3. Ahmed Abdullah AlAwadhi (2010): Factors influencing the marketing and e-commerce, the economy and society magazine, Faculty of Commerce, Kuwait, the sixth edition.

4. Ahmed Badr (200), information technology, study the integration of electronic resources, problem solving and the development of creativity, Journal of Arab libraries and information, year 20, No. 2, April.

\section{Ahmed Ramadan} Tawfiq Mohammed (2015): a proposed for e-commerce model in the field of sports in the Arab Republic of Egypt, unpublished $\mathrm{PhD}$ Thesis, Faculty of Physical Education for Boys in Cairo, Helwan University.

\section{Ahmed Taha Kurdi} (2014): aware risks have the final consumer in e-marketing and its impact in making a purchase over the Internet to users of the Internet in Egypt to buy of durable goods, unpublished Master Thesis, Assiut Journal For Sport Science Arts 
Faculty of Commerce, AlAzhar University.

7. Atkinson

Robert, (2005), "Proposing in an Era of Economic Development Journal / summer, pp. 33-37.

8. Bahaa Shaheen (2000): Globalization and e-commerce, a good house for publication and distribution the global and fittings, Cairo.

9. Bashar

al-Abbas

(2002): Internet marketing, institution Warraq for Publishing and Distribution, Amman, Jordan.

\section{Eleutherios, Dimitries} (2001): The development of B2c E-cornrnerce and Future.Eleutherios potential "llecrroni.Net Working Application and policy.

11. Efraim Turban, et al and others, (2006), Information Technology for Management: Transforming Organizations in the Digital Economy, 5thedition, Willey Higher Education, USA.

\section{2. fath Mojahedi (2007):} the digital economy and the requirements of the second International Forum (knowledge in light of the digital economy and its contribution in the formation of the competitive advantages for Arab Countries, Algeria, Faculty of economic sciences, management and laboratory globalization of the economies of North Africa. Http: //search.mandumah. com / Record / 570287

13. Fawazy El elmy (2008): the knowledge economy "Saudization minds," the Saudi newspaper Al Watan, No. 2748.8 April.

\section{Ghassan Abdul Hadi}

Ibrahim, the Arab common market. Even on the Internet, civilized dialogue, No. 31, September 2005 www.ahewarorg \debat \show.artasp.

\section{Hatem Osman Ali} (2009): The impact of emarketing practices on the market performance of the small businesses, unpublished $\mathrm{PhD}$ Thesis, Faculty of Commerce, Bradford.UK University.

\section{Hussein Mahdi (2005):} the digital economy in the Gulf Cooperation Council states (and the documents of the Second Annual Conference) Abu Dhabi, United Arab Emirates.

17. Hussein Omar Simari and Ashraf Sobhy Mohamed Hussein (2006): Egyptian 
investment and development of sports as results of the investment committee at the Ministry of Youth Evaluation Study, Journal of Menoufia University of Physical Education and Sports, the fifth year, No. IX.

\section{Haitham}

Salman

Abdullah (2005): economy, thus e-commerce in the GCC, the case of the "United Arab Emirates, Journal of Economics, Vol. IV study number 15.

\section{Ibrahim Mohammed} Darwish (2002): the tax processing of electronic transactions, research presented to the financial climate and investment conference held by the Faculty of Economics Sciences And administrative- Yarmouk University Irbid, Jordan, for the period October 29-31.

\section{Islam}

Mamoun Hussein (2011): the constraints that limit the success of e-commerce in Egypt, unpublished Master Thesis, British consultative status, the British Arab Academy for Higher Education, University of default International in the United Kingdom
21. Khalid Abdul Atiia (2000): proposal for the marketing of sports leagues ARE metho.ds. Unpublished MA Thesis fuclty Physical Education. Helwan University

22. Khairi Mustafa Kenana (2009): e-commerce, Dar march for publication and distribution, i 1, Amman.

23. Majdi Mohammed Abdullah (2016): readings and modern applications in emarketing and effective, what for publication and distribution, Alexandria.

\section{Mahmoud Qrziz and} Mary Yahyaoui (2007): "Reality and prospects of Arab economic cooperation in light of the challenges of the digital economy, the second International Forum" knowledge in light of the digital economy and its contribution in the formation of the competitive advantages for Arab Countries, Algeria.

25. Medhat Ramadan (2001): criminal protection for e-commerce "comparative study", Dar Arab Alnhzh, Cairo .s 12.

26. Mohamed Rumaihi (2005): the digital divide conflict, the International Al- 
Arab newspaper, No. 9815, October 2.

\section{Mohamad, El harery}

Bouchaor and omar Abboud (2007): The reality of $\mathrm{e}$ commerce in a digital economy (Second International Forum (knowledge in light of the digital economy and its contribution in the formation of the competitive advantages of the countries of the Arab League - Algeria.

28. Mohamed Khodry : the impact of the knowledge economy to achieve the competitiveness of Arab economies.

\section{Mohamed}

Ezzat

Ahmed (2013): The reality of e-marketing sports clubs, the Arab Republic of Egypt "analytical study", unpublished Master Thesis, Faculty of Physical Education for Boys, Helwan University, Cairo.

30. Mohamed Mohamud Abdullahi Yusuf: Cities of Knowledge Economy .. characteristics and challenges with exposure to the Egyptian experience of the College of Urban and Regional Planning Cairo University.

\section{Mohamed Mrayati} (2000): the knowledge economy: information technology and Arabization, Arabic magazine, electronic, club Arab information.

32. Omar Gzazi) 2008): the status of the information and communication technology in the knowledge economy, the second international scientific conference on management and intellectual capital measurement in organizations, the Arab Business - informant economic development and human - saad dahlab University of Blida, Algeria. The first volume, the first issue.

33. Rasha Duraid Hanna and Thaer Ahmed Saadoun al-Samman (2013): the use of information and communication technology in the knowledge flow applications "software model" Faculty of Management and Economics - University of Mosul of Iraq, Arab Journal of Management 0.53 folder, the first issue, in June) June).

34. Saed Elsafy (2006): the new regional and global challenges, the future of the Arab Journal, the Center for Arab Unity Studies, Year 29, No. 332.

35. Sana Abu Zeid (2005): The reality of e-commerce and 
the challenges faced by the Arab world and locally, Tishreen University Journal for Studies and Scientific Research, a series of of economic and legal sciences Vol 27, Issue 4

\section{Samanicgo.M.(2006):D}

eterminants of internet use in the purchasing process. Journal of Business\& Industrial Marketing "on -line.21. (3) Available: file://A Emerald. Host: Htm.

37. Sarwat El Sayed Ali EI Iraqi (2009) E-Commerce in the field of sports marketing sports clubs, Arab Republic of Egypt Unpublished MA Thesis, Faculty of Physical Education Zagazig University. 38. Tawfiq Mohammed Abdul Mohsen (2005): the challenges of marketing and ecommerce, Dar Arab Thought, Cairo.

\section{Scend:the websites}

39. http://www.internetworldst ats.com/ststs.htm

40. http//-

www.opendiretorgsite.infolecommerce

41. http://www.Nile7.com/rea dings

42. http://search.mandumah.co $\mathrm{m} / \mathrm{Record} / 586930$

43. http://www.internetindicat ors.com

44. http://www.Alriyadh.com 2005/12/30)

45. http://financialmanager.wo rdpress.com

46. http://arabs-e-markteting group.blogspot.com 